\title{
DOI: 10.7596/taksad.v6i4.1186
}

Citation: Lipich, T., Lipich, V., Penskaya, T., Penskoy, V., \& Pocheptsov, S. (2017). Legal Status of Moskovia during 16-17th Centuries. Journal of History Culture and Art Research, 6(4), 1305-1313. doi:http://dx.doi.org/10.7596/taksad.v6i4.1186

\section{Legal Status of Moskovia during 16-17th Centuries}

\section{Tamara I. Lipich ${ }^{1}$, Vasiliy V. Lipich ${ }^{2}$ Tatiana M. Penskaya ${ }^{3}$, Vitaly V. Penskoy ${ }^{4}$, Sergey S. Pocheptsov ${ }^{5}$}

\begin{abstract}
The authors of this article consider the development of the political, administrative and law spheres of the early modern Russian state against the backdrop of similar processes taking place in the neighboring states of Europe at this time. Analyzing the administrative and legal practices inherent in European states and in Russia of the late middle ages - early new age, the authors come to the conclusion that the notion of Muscovia, formed as a despotic state based on the absolute power of the Moscow tsars and the lack of rights of their subjects, is based on the subjective impressions of foreign observers. The latter, getting into the "closed" Moscow society, failed to understand the peculiarities of the Russian state power mechanisms functioning and their legal basis, based on traditions not recorded in written law. Having perceived the official Moscow political declarations as the real legal foundation, on which the early Russian state was built, foreign observers did not notice the everyday life behind this front façade, which had little in common with the officially proclaimed doctrine. The reality was to build a thin balance of interests between the supreme power and local government, based on the observance of "old traditions" by both sides. In this regard, the Russian state of the late middle ages - early new age can be considered a legal one, if we understand by "a law" not only the written law, but also the customary one.
\end{abstract}

Keywords: Late Middle Ages, Early New Age, Early Modern State, Customary Law, Western Europe, Russia.

\footnotetext{
${ }^{1}$ 308015, Belgorod, ul. Pobedy, 85, Belgorod State University. E-mail: lipich@bsu.edu.ru

2 308015, Belgorod, ul. Pobedy, 85, Belgorod State University.

3 308015, Belgorod, ul. Pobedy, 85, Belgorod State University.

${ }^{4}$ 308015, Belgorod, ul. Pobedy, 85, Belgorod State University.

${ }^{5}$ 308015, Belgorod, ul. Pobedy, 85, Belgorod State University.
} 


\section{Introduction}

An English diplomat and memoirist J. Fletcher, who visited Russia shortly after the death of Ivan the Terrible on a diplomatic mission, shared his impressions about the Russian judicial system in his notes besides everything else. In particular, he noted that the Muscovites "have no written law, save on the small booklet, that contained the time and manner of their sitting, order in proceeding, and such other judicial forms and circumstances". At the same time Fletcher continued his thought by expressing "nothing to direct them to give a sentence on right or wrong". Thus, "their only law is their speaking law, that is, the pleasure of the prince, and his magistrates and officers" (Fletcher, 1856: 69).

From this, (as from his other observations), Fletcher drew the conclusion about the tyrannical nature of a Moscow sovereign power and its weakness, since, in his opinion, the divided nobility and common people, unable to resist the tyranny of the tsar, based on the strength of the constant army, want "some foreign invasion, which they suppose to be on the average of these tyrannous government" (Fletcher, 1856: 45).

Fletcher was not alone in this description - many foreign observers of the same time agreed that Muscovy is the realm of tyranny and absence of rights based on lawlessness and where the only "law" is the will of a sovereign. Taking into account this point of view, based on the assessments of eyewitnesses and contemporaries, let's raise the following question at the same time - is this opinion really justified? It's no secret that foreign observers looked at the manners of the Muscovites from outside (and this is why their observations are valuable). However, without the "immersion" into the depths of Moscow everyday life, without a careful analysis of Moscow social-political and legal institutions operation, which was impossible without the work with the act materials and direct participation in the work of these institutions even as simple spectators, their observations are secondary and subjective. On the one hand, due to the peculiarities of the Moscow collective mentality, medieval one at its core, foreigners were considered as "others" with all the consequences. And the "closeness" of Moscow society (manifested even in the fact that the authorities sought to minimize the contacts of coming visitors, it was not important whether they were diplomats or traders) inevitably led to the fact that foreigners who arrived in Moscow did not see the whole picture, but only individual pieces of the mosaic.

On the other hand, L. Wolf pointed out that the image of the "other" since the middle of the 16th century was developed from the "western" side carefully, for "Eastern Europe defined Western Europe by contrast, as the Orientated the Occident" and, thus, Russia may resign its military domination of Eastern Europe, but it can not be banish the idea of Eastern Europe, for 
it did not invent or impose that idea, because "the idea of Eastern Europe was invented in Western Europe in the age of Enlightenment, and Russia was included in that idea" (with the only correction that Russia-Muscovy was withdrawn from the European "civilized world" much earlier - in our opinion, since the middle of the 16th century (Wolff, 1994: 7-15). Thus, foreigners came to Muscovy, already with certain mental attitudes, as a rule. Preparing to stay in the "other", "barbaric" country, they easily found these traits in the social and political legal system of Russia, especially since the Russians themselves gave them the reason for the lack of a cultural polish and the manners habitual for the Western Europeans of the Renaissance.

\section{Methodology}

In our small study, we rejected the rather popular concept of Muscovy as a despotic state (see, for example Poe, 2002) and proceeded from the provisions formulated in a number of historical works published in recent decades and changing our views on an early modern state. First of all, we took the concept of the so-called "composite state" as a methodological basis of our research. This concept was put forward by British historians G. Koenigsberger and J. Elliott to characterize the features of the early modern states of Western Europe (Koenigsberger, 1978; Elliott, 1992).

The idea expressed by G. Koenigsberger and his associates correlates well with the theses that were formulated in the works by V. Kivelson (1996), A. Berelovich (2001), N. Kollmann (1999, 2012), V.A. Arakcheev (2014), V.V. Bovykin (2012), V.V. Pensky (2015), etc. Turning not to narrative sources (primarily memos and memoirs) with their dense flair of subjectivism, but to the comparative analysis of early Russian legislation, the peculiarities of administrative and legal practices (first of all, of act materials, court records, bureaucratic correspondence, etc.) peculiar to the Moscow state in the late Middle Ages - the early New Time, they, like G. Koenigsberger, came to the conclusion that the state mechanism in Russia is weak and underdeveloped. Thus, in the attempt to compensate for this weakness, the supreme authority was forced to support local communities and elites, making concessions and compromises. Thus, the concept of "composite state" is not given by them directly, but the confirmation of it was found in Russian materials. "Composite state" can not be despotic by definition, because it is the result of a kind of compromise between the ruling elite and provincial elites and communities.

The management system (administrative, judicial, fiscal, etc.) in this kind of state is built as a complex conglomerate of vertical and horizontal links in which a significant role is played by a subjective moment, unwritten, customary law and tradition and custom in general. The 
supreme power is compelled to put up with them, because without a proper power and administrative resources, it can not ensure otherwise the loyalty of the territories attached to the crown, as agreed on cooperation and a kind of partnership with local societies and their leaders. These considerations seem particularly important from the point of view of political and legal development study methods in the late Middle Ages-the early New Times in respect of the Russian state and society, which determined our choice of precisely this concept as the methodological basis of our work.

\section{Results and discussion}

There is no doubt that the specific features of the political and legal structure of a particular state are primarily dictated by the specific historical conditions in which it has to evolve, and also by subjective circumstances (the peculiarities of a ruler personality, for example). According to the British historian R. McKenney, the 16th century for early modern Russia and for its neighbors was the century of expansion and a conflict (McKenney, 2002). Territorial expansion required much more resources than before, first of all human, material, financial, and the territorial expansion of early-modern states was called upon to solve this problem, at least partially.

However, territorial expansion was associated with two interrelated difficulties, and it was impossible to continue further aggressive foreign policy without their solution. These problems were related, on the one hand, with an effective work of the administration provision to mobilize the necessary resources in already subordinated and developed lands, and, on the other hand, with the organization of control and the possibility of exploitation in respect of newly acquired territories.

Theoretically, the strengthening of central power, the concentration in the hands of a supreme sovereign, if not all, then the main powers had to guarantee the solution of these problems. And the more powerful the supreme power is, the more effectively a state works in theory. And, at first glance, the supporters of the concept of Muscovy as a despotic state (Poe, 2002) in this situation have an undoubted advantage.

The "mobilization" nature of such a super-centralized state would seem to give it undoubted advantages over rivals, and the history of the territorial expansion of Muscovy in the 16th century confirms this. However, at the same time, the defender of the thesis about the despotic character of Moscow sovereign power, willingly or unwillingly, "overthrows" the realities of the nineteenth and twentieth centuries in the early modern time, when a state gained real strength. 
Such presentation distorts the picture of a historical reality which existed 400 - 500 years ago. In the specific historical conditions of the late Middle Ages - early New Times, the supreme power faced a number of objective problems (and especially in the Russian case), which were almost impossible to solve in the conditions of that period. The lack of not only qualified, but also literate people, capable to perform more or less satisfactorily administrative, managerial and judicial functions, a constant shortage of financial resources, a weakly developed infrastructure (especially roads) and significant distances that made it more difficult to maintain a more or less regular communication with the provinces - all this necessitated the establishment of some mutually beneficial cooperation with local communities.

This interaction, and only it, could guarantee more or less long-term loyalty of provincial population and elite, and, therefore, the stability of the social-political situation and the normal operation of a state machine. As was noted by N. Kollmann, in the early modern states (and Russia was no exception to this rule) "legitimacy was grounded not only in the measured deployment of state-sanctioned violence, but also in the state's fulfillment, to a greater or lesser degree, of expectations that the ruler would respond to his people, respect tradition and provide security" (Kollmann, 2012: 416].

"Would respond to his people, respect the tradition and provide security?" - these are the qualities that are traditionally denied for Moscow supreme authority as was mentioned above. Such a negative characterization of the relationship between power and society in early Russia is related, in our opinion, with the fact that foreign observers, not being "included" in Moscow's daily routine, observed only its external, formal side, which was reflected in the autocratic discourse. However, what were the principal differences of this discourse, for example, from the declarations of the classical absolutist monarch of modern times Louis XIV? After all, as was noted by the British historian N. Henschel, the absolutism of the Sun King was manifested in the fact that "whether Louis was made up himself with it, it was royal authority which was invoked and could not be legitimately resisted". And in this sense "the king's power was absolute" (Henshall, 1992: 37). At the same time, the decision-making mechanism remained behind the scenes and it was very far from formal absolutism.

This is equally true of Muscovy. Foreign observers, confronted with Moscow's autocratic discourse, took it at its face value, since this, on the one hand, was in line with their expectations. After all, brought up in the humanistic, Renaissance tradition, they proceeded from the fact that the East is the territory where despotism traditionally dominates, limited by nothing and no one. And faced with Moscow's political declarations and official practices, they noted with satisfaction that what we expected, what we saw indeed. 
On the other hand, informal Moscow political, administrative and judicial practices, based mainly not on written law, but on custom and tradition, remained behind the scenes for foreigners. And we cited the above mentioned quotation from the study by N. Kollmann not accidentally, for she pointed to the most important feature of early-state states aptly - society expected from the ruler that he would observe tradition and custom, guaranteeing him his loyalty and support in return. If we turn to Russian "political" literature of the late Middle Ages - early New Times, we can find the evidence to support this thesis easily. So, for example, the refusal to observe the tradition by Vasily III was criticized by the first Russian dissident Bersen Beklemishev. And Ivan the Terrible was subjected to harsh and impartial criticism from another, more famous Russian dissident of that era, Prince Andrew Kurbsky, for the innovations in the political and administrative sphere and in administration methods. The dissatisfaction by Beklemishev, Kurbsky and their associates can be understood, for the same Vasily III, and Ivan IV, acting in the spirit of the early modern European monarchs, "terminated the feudal dispersion of sovereignty, when local lords enjoyed prerogative or regal rights" (Henshall, 1992: 82). But at the same time, paraphrasing the thesis by $\mathrm{N}$. Henshell, the Moscow sovereign "himself was above the custom and under it, although no paradox was intended. He was below the custom because he was supposed to recognize the subjects of 'rights which it guaranteed' ..." (Henshall, 1992: 82). Fighting against the notorious "feudal dispersion of sovereignty" both Basil III and Ivan IV fought specific people, but not the very idea of political, administrative and legal conservatism. This can be confirmed by the analysis of the treaty texts between the Grand Dukes and provincial princes, in which the spheres of competence and jurisdiction were clearly delineated - the contracting parties mutually agreed not to interfere in the internal affairs of the territories controlled by each of the parties to the treaty, observing the sovereign rights of each other as rulers. Custom and tradition were observed here fully, and the same Ivan IV, having executed his cousin Vladimir Staritsky on the charges of treason, nevertheless endowed the son with his father's territory, without encroaching on tradition and custom-established law.

In summary, our analysis of the act and narrative materials allows us to conclude that the answer to the issue posed by us can be formulated as follows. The foreigners who were unaware of Russian legal practices in the informal, unseen side of Moscow's political, administrative and legal practices, accepted the official political declarations of the Grand Dukes at face value (especially since they met their expectations). Meanwhile, the Moscow sovereigns, like Western European monarchs who were contemporaries, had no real opportunity to make their subjects do what they consider necessary, due to the weakness and 
underdevelopment of the administrative apparatus, were forced to compromise with society (or rather, societies, local societies, corporations represented by servicemen, merchants, craftsmen, peasants, etc.). On the one hand, they guaranteed that, if loyalty is respected, they will not touch the "old traditions", but on the other hand, within the same old traditions, they attracted local communities and corporations to manage the affairs. At the same time, Moscow has divided the spheres of competence between the central government and local communities and corporations. As was noted by N. Kollmann, "the state set itself minimal goals, concentrating on warfare, collecting revenue and manpower and providing the highest justice" (Kollmann, 2012: 417), i.e. focused on what was called "a matter of a sovereign" in Moscow's written culture. Local self-government was given to local authorities. "Communities" selected "members to serve as brigandage elders, bailiffs, prison guards, executioners, chiefs of alcohol and other monopolies. All able-bodied men joined in posses to chase down criminals. Villages, urban communes, seigneurial and monastic estates, the historian continued his thought (Kollmann, 2012: 417).

But in the conditions when the execution of the "tsar's case" depended on how the Zemsky case would be done, the supreme authority would inevitably have to cooperate with the "land", with local self-government. The loyalty of the latter was guaranteed in the event that the supreme power observed the traditional "liberties", fixed by the custom. And although these customs were not fixed in written law, were not codified, they did not become less effective. This detail, this feature of Moscow's administrative and legal practices has slipped away from foreign observers, brought up and nurtured in the traditions of classical Roman law. The fact that the Muscovites honored not the letter, but the spirit of the "law" (represented by the custom) was considered as nonsense for the Europeans. However, their opinion was not interesting for Moscow sovereigns - Muscovy of those times was quite a selfsufficient society, and was based on the observance of the tradition and the custom of political and legal being was perceived as a reality, familiar and understandable within the value system in which Muscovites were upbrought. The observance of the custom for them seemed to be an obvious sign that an unspoken "social contract" between the government and society continues to function, and, therefore, the government is legitimate and the state is legal (but, again, this is based on the observance of custom and not a written law).

\section{Conclusions}

The opinion recorded in literature, including scientific one and in public, the view according to which the early Russian state, Muscovy was a despotic state in which a sovereign's will was law, and that his subjects had no rights in the face of an autocratic, absolutist supreme 
power, is not true. It was based primarily on the biased and subjective opinion of foreign observers, for whom Moscow's administrative and legal practices, based primarily on unwritten law, on custom and the observance of traditions, went unnoticed and misunderstood. On the contrary, the official declarations of the Moscow authorities fell perfectly into the antinomy "West-East", where the rule prevailed in the West, and the will of the monarch prevailed in the East, limited by nothing and no one.

However, the appeal not to narrative sources, but to factual materials, court cases and legislation shows that in reality the picture was more complicated and the nuances of it escaped from the attention of foreigners because of Moscow society "closeness". Administrative and legal practices in the Russian state of the 16th and 17th centuries were based on the balance of interests and the cooperation between the supreme authority and the local lands, the central administration and local self-government, and custom and tradition acted as a connecting element of this system. The observance of a kind of "social contract" by both sides was based on the conviction that custom and tradition are the primary right as a universal regulator of the entire system of social relations and guaranteed the functioning of the entire mechanism of state power from top to bottom. And in this sense, the Russian state of early modern times can be considered as legal one.

\section{References}

Arakcheev, V. A. (2014). Power and land. The government policy concerning estates in Russia in the late XVI-early XVII centuries. Moscow: Depository of ancient manuscripts.

Berelowitch, A. (2001). La hierarchie des egaux. La noblesse russe d'Ancien Regime (XVIXVII siecles). Paris: Editions Seuil.

Bovykin, V. V. (2012). Self-governance in the Russian state in the XVI century. SaintPetersburg: Dmitri Bulanin.

Elliott, J. H. (1992). A Europe of Composite Monarchies. Past \& Present, the Cultural and Political Construction of Europe, 137.

Fletcher, G. (1856). Of the Russian Common Wealth. Russia at the Close of the Sixteenth Century. London: The Hakluyt Society.

Henshall, N. (1992). The Myth of Absolutism. Change and Continuity in Early Modern European Monarchy. London and New York: Longman.

Kivelson, V. A. (1996). Autocracy in the Provinces. The Muscovite Gentry and Political Culture in the Seventeenth Century. Stanford: Stanford University Press.

Koenigsberger, H. G. (1978). Monarchies and Parliaments in Early Modern Europe Dominium Regale or Dominium Politicum et Regale. Theory and Society, 5(2). 
Kollmann, N. S. (1999). By Honor Bound: State and Society in Early Modern Russia. Ithaka \& London: Cornell University Press.

Kollmann, N. S. (2012). Crime and Punishment in Early Modern Russia. Cambridge: Cambridge University Press.

McKenney, R. (2002). Sixteenth Century Europe. Expansion and Conflict. London: Palgrave Macmillane.

Penskoy, V. V. (2015). Saint or "Erbfeind gantzer christenheit"? Ivan the Terrible and his era: character and reality. Research result. Social Studies and Humanities, 3(5).

Poe, M. (2002). The Truth about Muscovy. Kritika: Explorations in Russian and Eurasian History, 3(3).

Wolff, L. (1994). Inventing Eastern Europe. The Map of Civilization of the Mind of the Enlightenment. Stanford: Stanford University Press. 